\title{
obituary
}

\section{B. E. Bykhovskii}

Academician Boris EVSEEVICH BYKHOVSKII, a leading Soviet parasitologist, and Director of the Institute of Zoology of the Academy of Sciences of the USSR, died on January 26, 1974.

Bykhovskii was born in 1908, in St Petersburg, and was educated at Leningrad University, graduating from the Biology Department in 1930. His first scientific post was as a laboratory assistant at the Institute of the Fishery Industry; by 1939, when he left the Institute, he had risen to the rank of senior scientist. In 1939, he moved to the Institute of Zoology of the Academy of Sciences of the USSR, which was from then onwards the centre of his scientific activity. From 1940-44 he worked in Tadjikstan as Deputy Chairman of the Tadzhik branch of the Academy, playing a great part in the transformation of this branch into the new Academy of Sciences of the Tadzhik SSR. From 1942-59 he was Head of the Laboratory of Helminthology of the Institute of Zoology of the Academy of Sciences of the USSR, and, simultaneously and until 1962, Deputy Director of the Institute of Zoology. In 1962 he became director of the Institute, a post which he was to hold for the rest of his life. In 1960 he was elected a Corresponding Member and in 1964 a Full Member of the Academy of Sciences of the USSR.

Bykhovskii's main field of research was the helminths of fish. His publications, however, deal with a considerable range of associated problems of general parasitology, ecology and evolution. He organised over twenty-five scientific research expeditions and was founder and Editor in Chief of the journal Parasitologiya.

His best-known papers include Contributions to Knowledge about Monogeneic Trematodes with a Primitive Fastening Armature (1955); Informa- tion on Monogeneic Trematodes in the Fishes in Tadjikstan (1960); The Monogeneic Trematodes of Silarus glanis (1966); and Results and Further Prospects of the Work of Soviet Parasitologists in the Study of Parasites of Fish in the Seas of the USSR.

In September 1965, at the joint session of the Presidium of the Academy of Sciences of the USSR and other scientific institutions, Bykhovskii was among those who strongly criticised Lysenkoism and its adverse effect on Soviet science. His support for the antiLysenkoists was of particular importance, as, unlike several other critics, Bykhovskii was a keen Party member with an active interest in politics, and from time to time held official positions in the Leningrad City and Regional Party organisations.

For his services to science and to the fishing industry, Bykhovskii was awarded a number of Soviet decorations including the Order of Lenin and the Order of the Red Banner of Labour.

\section{P. K. Anokhin}

Academician Petr. Kuz'mich Anokhin, the eminent Soviet physiologist and brain specialist, died on March 6, 1974.

Anokhin was born on January 27, 1898 , in Tsaritsyn (later Stalingrad and now Volgodrad). The son of a worker, he began his studies at the local agricultural and technical college, but, in 1917, these studies were interrupted by the revolution. Anokhin, whose sympathies were with the revolutionaries, took an active part in the defence of Trasitsyn and in the establishment of Soviet rule in the Don area, becoming, towards the end of the civil war, Commissar of Publications in Novocherkassk, and editor of the newspaper Krasnyi Don. In this latter capacity, while browsing for subject matter for popularised science articles, he happened upon a publication of the Leningrad Brain Institute, and became fascinated by the work of Bekhterev and Pavlov on conditioned reflexes.

When the civil war ended, Anokhin was able, through the intervention of A. V. Lunacharskii, People's Commissar for Culture, to transfer his studies to the Leningrad Institute of Medical Science where he graduated in 1926. After graduation, he proceeded to Pavlov's own laboratory, working and studying under Pavlov and Bekhterev until 1930, when he was appointed Professor of the Department of Physiological Medicine at the University of Gor'kii, a post which he held until 1934. Later positions included Head of the Department of General Physiology of the Higher Nervous System at the AllUnion Institute of Experimental Medicine (1934-46), Director of the Institute of Physiology of the Academy of Medical Sciences of the USSR (194649), Head of the Departments of Physiology and Pathology of the Higher Nervous System at the Central PostGraduate Medical Institute (1936-49 and 1953-55), and Head of the Department of Normal Physiology of the I. M. Sechenov Moscow Medical Institute. During the Second World War he served as neurosurgeon and assistant to the renowned surgeon Nikolai $\mathbf{N}$. Burdenko.

Throughout his working life, Anokhin maintained the interest in conditioned reflexes and the action of the brain, which had first attracted him to neurophysiology. He extended and amended Pavlov's fundamental ideas in the light of later research and put forward a highly complex picture of brain reaction to stimuli, involving a number of areas of the brain, including subcortical areas. One of his postulates was that some 'intention' to perform an action must emerge between stimulus and reaction. Other fields in which he did notable work included the physiological theory of the neural cicatrix, the theory of pathogenesis of amputation pains and central paralysis, and medical cybernetics.

His numerous publications inchude Problem of the Central and Peripheral Nervous systems in the Physiology of Nervous Activity (1935); Neuroplasty for Battle Injuries of the Peripheral Nervous System (1944); Systemogenesis as a General Rule of the Evolutionary Process (1948); General Principles of the Compensation of Functional Perturb. ances and their Physiological Basis (1954), Internal Inhibition as a Problem of Physiology (1958); and The Biology and Neurophysiology of the Conditioned Reflex (1967) for which he was awarded a Lenin Prize in 1972. He also wrote a life of Pavlov (1949), edited a number of collections of essays (the most recent being Cybernetic Aspects in Studying Brain Action (1970)), was Physiology Editor for the large and small medical encyclopaedias and contributed a preface to the Russian edition of R. Ashby's Construction of the Brain.

$\mathrm{He}$ was a member of the Executive Committee of the International Organisation for Brain Research, and represented his country at a number of international conferences, including the 
International Congresses of Physiologists in Brussels, 1956), and Buenos Aires (1959), the International Organisation for the Study of the Brain (Paris, 1960 ) and the International Symposium on the Development of the Brain (USA, 1963). He was elected a member of the Academy of Medical Sciences of the USSR in 1945 and a member of the Academy of Sciences of the USSR in 1966.

\section{Announcements}

\section{Appointments}

Robert C. Seamans, jr., has been reelected President of the National Academy of Engineering.

\section{Awards}

J. Erik Jonsson has been awarded the Founders Medal of the National Academy of Engineering.

Ivar Giaever has been awarded the Vladimir K. Zworykin Award of the National Academy of Engineering.

\section{Corrigendum}

In the article "New species of Dryopithecus from Kenya" by P. Andrews (Nature, 249, 188; 1974), in the description of Rangwapithecus, a new subgenus of Dryopithecus, the type species of the new subgenus is the one first listed, namely Dryopithecus (Rangwapithecus) gordoni.

\section{Erratum}

In the article "The neunogenic and myogenic hypotheses in human (Duchenne) muscular dystrophy" by W. H. Thomson, J. C. Sweetin and R. A. Elton, (Nature, 249, 151; 1974) in line 9 of the legend to Fig. 1, 33 should read 23.

\section{Reports and publications}

\section{Great Britain}

World Health Organization. International Health Regulations (1969). Second annotated edition. $\mathrm{Pp}_{\mathrm{p}}$ 102. (Geneva: WHO; London: HMSO, 1974.) Sw. fr. 6 .
[2i1 Berichte des Deutschen Wetterdienstes. Nr. 132 des Dentchen Wetstand des Baroklinen Modell fung Numerischer Vorbersagekarten 1970 PruVon W. Buschner, H. Oeckel, J. U. Schwirner und K. O. Wegner. $\mathrm{Pp}_{\mathrm{p}}$ 38. Annalen der Me. teorologie (Neue Folge) Nr. 8: Die Entwicklung der Meteorologischen Beobachtungen in Kranken und Bayern bis 1700 . Von FritzKelnim. Pp. 50. Annalen der Meteorologie, (Neue Folge), Nr. 7: The Planetary Boundary-Layer of the Atmosphere. By F. Winpermann. Pp. $\mathbf{x}+346$. (Offenbach a.M.: : Selbstverlag des Deutschen Wetterdienstes,
[1973.)

US Department of Health, Education and Welfare. Public Health Service-National Institutes of Health. National Cancer Program. Report of the Director, January 1973. Pp. 42. Report of the Pp. 1.1. The Strategic Plan, January 1973 Edition. Digest of Scientific Recommendations for the Department of Health Education and Welfare, Na Department of Health Education and Welfare, Na-
tional Institute of Health, 1973.)
[221

CERN-European Organization for Nuclear Research. CERN 73-17: Elements d'Analyse Nu-
merique et leur Programmation en Fortran IV. Premiere partie: Calcul des Derivees Successives Premiere partie: Calcul des Derivees Successives
d'Une Fonction d'Une Variahle Reelle. Applications aux Developpements de Taylor, de Burmann et de Thiele. Par F. Louis. Pp. 61. (Geneve: ERN, 1973.)

$[23$

World Health Organization. Public Health Pa.
ers No. 54: Control of Air Pollution in the pers No. 54 : Control of Air Pollution in the WHO; London: HMSO, 1973.) Sw. fr. 9; $£ 1.35$.

European Space Research Organization. General Report 1972. Pp. 230. (Neuilly-sur-Seine: [231

World Health Organization. Technical Report Series, No. 532: Trace Elements in Human NuPp. 65. (Geneva: WHO; London: HMSO, 1973.)
Prition- HM Sw. fr. 5; $75 \mathrm{p} ; \$ 1.75$.

[28 The Development of Electronic Data Processing in Manpower Areas. Pp. vii +350 . (Paris World Health Organization. Technical Report Series. No. 533: Postgraduate Education and Training in Public Health-Report of a WHO Expert Committee. Pp. 68. 5 Sw. francs; $75 \mathrm{p}$; sicians-Report of a WHO Expert Committee. $\mathrm{Pp}$. 32. 5 Sw. francs: 75p; \$1.75. (Geneva: WHO; Carte de la Végétation du Bassin Genevois. Notice Abrégée de la Carte de la Végétation du Bassin Genevois. Par P. Hainard et G. Tchérénissinoff. Pp. 19 (Genève: Conservatoire et
Jardin Botaniques. 1973.)
[291

Canada: Department of Energy, Mines and Re sources. Geological Survey of Canada. Paper 74-1. Part A: Report of Activities. Part A: April to October 1973. $\mathrm{Pp}$. 396. (Ottawa: Information Canada, 1974.) $\$ 5$

[291

Guide to Information Services in Marine Technology. Compiled by Martran Linited. Pp. Ileriot-Watt University, Chambers Street, 1973.) ¿1. 1973/1973 Pp. iii 37 (Risley, Warrington, Lancs.: Universities Research Reactor, 1974.)

Bulletin of the British Museum (Natural History). Geology Supplement 10: A Revision of the Elopiform Fishes, Fossil and Recent, By P. L. Forey. Pp. 1-222. (London. British Museum Natural Environit wood Research Station-Report for 1970/1972. Pp. 66+9 plates. (Grange-over-Sands, Lancashire: Natural Environment Research Council, Institute of Terrestrial Ecology, Merlewood Research Station, 1973.) $50 \mathrm{p}$

The Conmonwealth Forestry Institute, University of Oxford. Forty-ninth Annual Report, 1972/ 1973. Pp. 32. (Oxford: The Commonwealth For estry Institute, 1973.)

Linear and Multilinear Algebra, Vol. 1. No. 1. 1973. Edited by M. Marcus and R. C. Thompson Pp. 1-88. (London and New York: Gordon and
Breach, 1973.) The Zoological Record. 1970. Volume 107. Section 4: Coelenterata. Compiled by the Staff of the Zoological Society of London. Pp. 55. £5.15. 1970, by the Staff of the Zoological Society of pondon. $\mathrm{PR}$. 36. $\{3.65$. (London: The Zoological London. Pp. 36. $\{3.65$. (London: The Zoologica]
Society of London, 1973.) London School of Hygiene and Tropical Medicine. Report on the work of the School, 1972/1973 Pp. 177. (London: London School of Hygiene and
Tropical Medicine, 1974.)
[212
Government Statistics: a Brief Guide to Sources. Pp. 16. (London: Central Statistical Office, Great George Street, SW1, 1974.)

Philosophical Transactions of the Royal Society of London: B: Biological Sciences. Vol. 267. No. 885; The Central Nervous System of Loligo. 1: The Optic Lobe. By J. Z. Young. Pp. 263-302 t 267. No. 886: On the Growth and Form of $a$ Bacterial Cell. By R. H. Pritchard (Review Lecture). Pp. 303-336. UK £1.20; Overseas £1.25.
(London: The Royal Society, 1974.) Medical Research Council. National Institute for Medical Research-Report for 1972/3 Pp. 150. (London: National Institute for Medical Re-
[282, search, 1974.) Vol. 78, Part 1: Fine Structure in Radio Sources at $81.5 \mathrm{MHz}$-III. The Survey. By A. C. S. and London: Blackwell Scientific Publications, 1974. Published for the Royal Astronomical
ciety.)
28 ?

\section{Other countries}

Anuario del Observatorio Astronomico de Madrid papa 1974. Pp. 386. (Madricl: Observatorio Astronomico, Aifonso XII, 3, 1973.) [212 Bibliographien des Deutschen Wetterdienstes, Nr 27: Agrarmeteorologische Bibliographic 1972. 225. (Offenbach Maximilian Schneider. Pp. xixt Wetterdienstes, 1973.)

Bulletin of the Fisheries Research Board of Can. acla, No. 182: Morphology and Sediments of the Gulf of St. Lawrence. By D. H. loring and D. J. G. Nota. Pp. xiv+147. (Ottawa: InforLe Conseil des Recherches Agricoles du Québec. Recherches Agronomiques-Sommiaire des Résultats, 1971/1972, No. 17. Pp. 157. (Quebec: Ministère de l'Agriculture et de la Colonisation,
1974 .) 1974.)
Technology of Efficient Energy Utilization. (The Report of a NATO Science Committee Conference held at Les Arcs, France, 8th-12th October, 1973.) Pp. xiv +67 (Brussels: Scientific Affairs
Division, North Atlantic Treaty Organization, Division, North Atlantic Treaty Organization,
1974.) United States Department of the Interior:
Geological Survey. Bulletin 1304: Mineral ReGeological Survey. Bulletin 1304: Mineral Re-
sources of the Idaho Primitive Area and Vicinity, Idaho. By F. W. Cater ct al. Pp. xiv-1431. (Washington, DC: Government Printing Office, 1973.)
$\$ 4.65$. Office de la Recherche Scientifique et Technique Outre-Mer, Paris. Initiations--Documentations Techniques No. 22: Par P. Ségalen. Pp. 279. (Paris et Bondy: Office de la Recherche Scientifigue et Technique Outre-Mer, 1973.) 100 francs.
[?52 European Organization for Nuclear Researcl Separated Bubble Chamber Beams. By P. Lazeyras, I. Lehraus, R. Matthewson and W. Tejessy. ras, 72. (Geneva: CERN, 1974.) and
Pp. [253 of the Introduction of Food Irradiation in De. veloping Countries. (Proceedlings of a Panel to Consider the Application of Food Irradiation in Developing Countries, organizer by the Joint and Agriculture, and held in Bombay, 18-22 $\mathrm{No}$. vember 1972.) $\mathrm{Pp}$. 113. (Vienna: IAEA: London: HMSO, 1973.) 108 schillings; $£ 2.50 ; \$ 6$.

Mitteilungen aus der Biologischen Bundesanstalt fuir Land- und Forstwirtschaft, Berlin-Dahlem. Heft 154: Festveranstaltung und Internationales Kolloquium zum 75 Jährigen Jubilaum der Biologischen Bundesanstalt für Land. und Forstwirtschaft. Pp. 115. 10 DM. Heft 155: Thesaurus Phytomedizin (Pflanzenkrankheiten und Pflanzenschutz). Von Dr. D. Bulmenbach. Pp. 145. 14.50 für Land- und Forstwirtschaft, 1973.) [262 The International Nickel Companv of Canada, I.td. 1973 Annual Report. Pp. 28. (Toronto: The
International Nickel Conipany of Canada, Ltd., 1974.)

Smithsonian Contributions to Zoology. No. 149: Ecology and Behavinr of the Giant Wrod Spider Nephila maculata (Fabricius) in New Guinea. By iv 76. \$1.45. No. 159: Clinid Fishes of Chile and iv+76. \$1.45. No. 159: Clinid Fishes of Chile and Peru, with Description of a New Species, Mrrodes
ornatus, from Chile. By John S. Stephens, Ir. and ornatus, from Chile. By John 5 . Stephens, fr. and ton, DC: Smithsonian Institution Press, 1973. For ton, DC: Smithsonian Institution Press, 1973. T20r Annals of the Transvaal Miuseum. Vol. 29, No. 1: Some Suggested Procedures in the Analysis of Bone Accumulations from Southern African Quaternary Sites. By C. K. Brain. Pr. 1-8. Vol. 29, No. 2: South African I.epidontera, 6 Notes on Hesperiidae and Descriptions of Two New Species $26+$ plate 1. (Pretoria: Transvaal Mruseum, 1974.) plate 1. (Pretoria: Transvaal Museum, United States Department of the Interior: Gelogical Survey. Professional Paper ment Rocks. By Robert H. Tschudy. Pp. iiit15 (nlates 1 - 9). (Washington, DC: Government 